\title{
Blended Learning Kegiatan Kajian dan Praktik Lapangan Mahasiswa di SMK
}

\author{
Mifta Dewayani*, Aji Prasetya Wibawa*, Yongen Susman**
}

*Universitas Negeri Malang, Jl. Semarang No.5 Kota Malang 65145, Indonesia

${ }^{* *}$ SMK Negeri 1 Blitar Jl. Kenari No.30, Plosokerep, Kec. Sananwetan, Kota Blitar, 66134 Indonesia

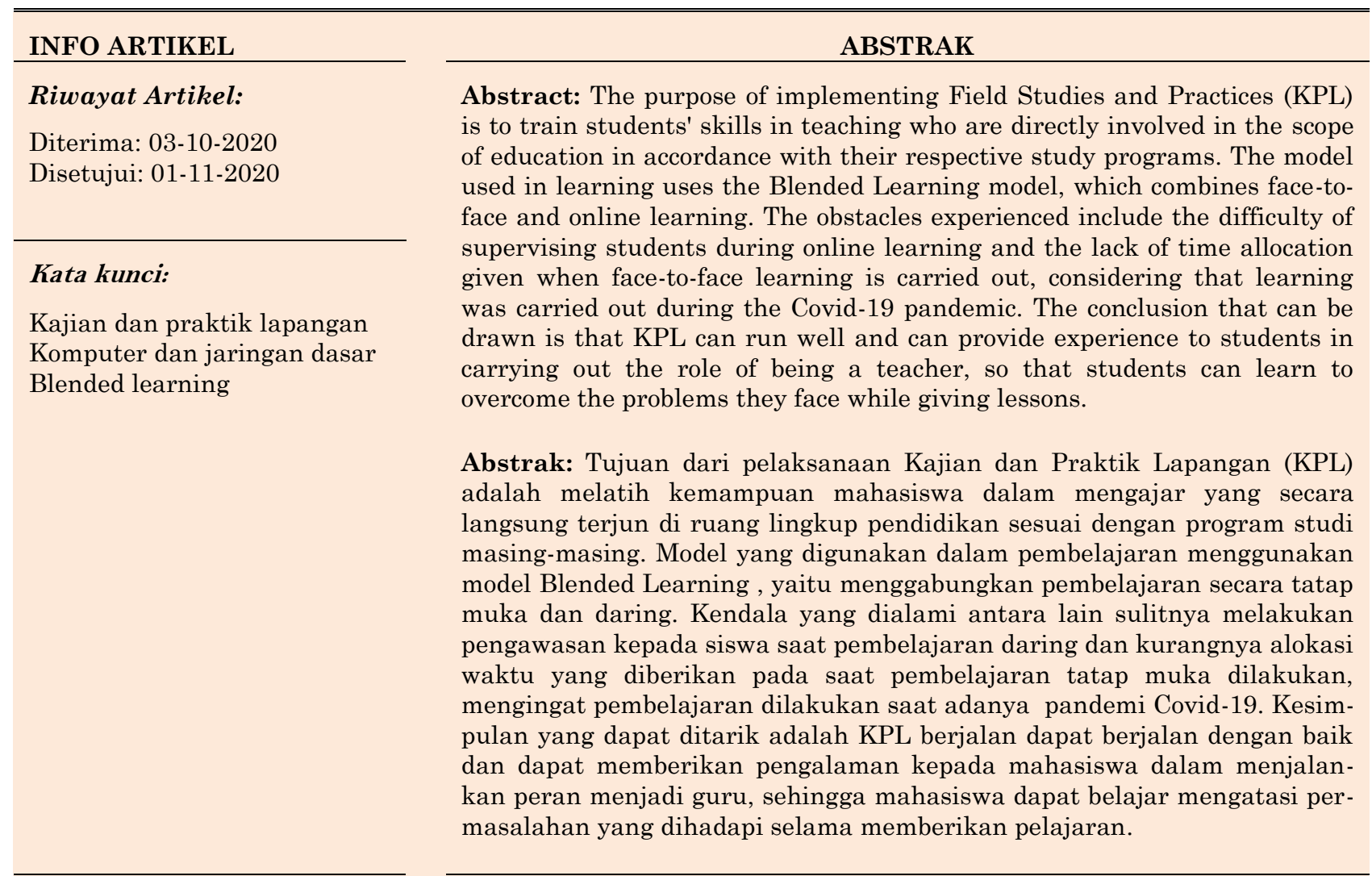

\section{Alamat Korespondensi:}

Aji Prasetya Wibawa

Jurusan Teknik Elektro

Fakultas Teknik

Universitas Negeri Malang

Jl. Semarang No.5, Sumbersari, Kec. Lowokwaru, Kota Malang, 65145 Indonesia

E-mail: aji.prasetya.ft@um.ac.id

\section{PENDAHULUAN}

Kajian dan Praktik Lapangan atau disingkat dengan KPL adalah salah satu mata kuliah wajib bagi mahasiswa program studi pendidikan. Mata kuliah KPL memberikan kesempatan kepada mahasiswa dalam memberikan pengalaman dan mengembangkan ilmunya sehingga mahasiswa memiliki kompetensi yang memadai dalam melaksanakan tugas sesuai dengan bidang masing-masing (Pradhitya et al., 2018). Melalui kegiatan KPL, diharapkan terbentuk tenaga profesional yang berpengalaman dalam menerapkan ilmu dan bidang garapannya. Pelaksanaan KPL Gelombang 1 di SMK Negeri 1 Blitar jurusan TKJ diikuti oleh 6 mahasiswa dari program studi Pendidikan Teknik Informatika, dimana masing-masing mahasiswa 
mengampu mata pelajaran yang berbeda-beda. Secara umum model pembelajaran yang digunakan mahasiswa KPL adalah model Blended Learning, mengingat KPL ini dilaksanakan saat pandemi Covid-19.

Blended learning adalah penggabungan aspek format elektronik seperti pembelajaran berbasis web, streaming video, komunikasi audio synchronous dan asynchronous dengan pembelajaran tradisional "tatap muka" (Sjukur, 2012). Tujuan blended learning adalah untuk memberikan pengalaman pembelajaran yang paling efektif dan efisien (Idris, 2018). Menurut Carman (Syarif, 2012), terdapat lima hal yang harus diperhatikan dalam menggunakan model blended learning, yaitu: (1) pembelajaran tatap muka dalam waktu dan tempat yang sama atau waktu sama tapi tempat berbeda; (2) mengkombinasikan dengan pembelajaran mandidi yang memungkinkan siswa dapat belajar dimana saja dan kapan saja; (3) mengkombinasikan kolaborasi antar pengajar dengan siswa maupun antar siswa; (4) pendidik harus mampu mengkombinasikan jenis assesment online dan offline; (5) bahan aja harus disiapkan dalam bentu digital yang dapat diakses oleh siswa secara online maupun offline.

Permasalahan awal yang dihadapi oleh mahasiswa adalah kurangnya kepercayaan diri yang disebabkan mahasiswa belum memiliki pengalaman dalam mengajar. Dengan demikian perlu adanya pembekalan dan memberikan waktu untuk adaptasi bagi mahasiswa calon pendidik, sehingga mahasiswa dapat menganalisis hal-hal apa saja yang perlu dipersiapkan sebelum melakukan proses belajar mengajar. Berdasarkan latar masalah di atas, penulisan artikel ini bertujuan untuk mendeskripsikan kegiatan KPL yang dilaksanakan oleh mahasiswa program studi Pendidikan Teknik Informatika di SMK Negeri 1 Blitar. Menurut McKenzie et al. (Mustafa, 2020) dalam sistematika pelaksanaan KPL harus melalui beberapa langkah, yaitu: (1) perencanaan, (2) pelaksanaan, dan (3) evaluasi.

\section{MIETODE}

Secara ideal, dalam proses belajar mengajar guru sebagai pendidik memiliki tugas untu mendorong, membimbing, dan memberi fasilitas belajar bagi siswa untuk mencapai tujuan pendidikan (Hashona, 2016). Dalam mencapai tujuan pendidikan, perencanaan merupakan hal yang paling penting sebelum dilakukan kegiatan pembelajaran. Dalam pelaksanaan KPL, mahasiswa terlebih dahulu berkoordinasi dengan pihak sekolah untuk menentukan jadwal megajar, kemudian mahasiswa berkonsultasi dengan guru pengampu mata pelajaran Komputer dan Jaringan Dasar untuk mengetahu apa saja yang perlu dipersiapkan, mulai dari pembuatan Rencana Pelaksanaan Pembelajaan (RPP) dan perangkat pembelajaran lainnya, materi yang disampailkan, metode dan model pembelajaran serta bahan ajar yang digunakan.

\section{Rencana Pelaksanaan Pembelajaran}

Dalam pembuatan Rencana Pelaksanaan Pembelajaran (RPP), mahasiswa ditugaskan untuk membuat mulai dari KD 3.1/4.1 sampai dengan KD 3.6/4.6 mata pelajaran Komputer dan Jaringan Dasar. Selain itu, mahasiswa juga diminta untuk membuat Program Tahunan, Program Semester, Daftar Hadir Siswa, Rekap Rekap Nilai Siswa, Silabus, Kalender Pendidikan, Jadwal Blok, Jadwal Pelajaran, hingga Analisis Hari Efektif Mengajar yang dimuat dalam dokumen yang bernama perangkat pembelajaran.

\section{Analisis Kebutuhan}

Setelah membuat RPP, mahasiswa membuat media pembelajaran yang akan digunakan untuk menyampaikan materi. Untuk menunjang kegiatan pembelajaran daring, mahasiswa membuat media pembelajaran yang berupa materi dalam bentuk PPT dan tugas yang diupload di E-Learning sekolah, serta video pembelajaran yang diupload di-YouTube. Sistem pendidikan e-learning yang dilaksanakan secara tepat di sekolah dapat membantu dalam menyelesaikan masakah-masalah pembelajaran yang tidak dapat diselesaikan di kelas (Fatahillah et al., 2020), akan tetapi menurut Pilkington (Fitriyani et al., 2020) tidak bisa dipungkiri bahwa tidak semua pembelajaran dapat dipindahkan ke dalam lingkungan pembelajaran secara online. Sedangkan Youtube merupakan situs video upload yang banyak digunakan untuk berbagi video (Chandra, 2018).

Pembelajaran daring mata pelajaran Komputer dan Jaringan Dasar setiap kelas dilakukan selama 2 minggu sekali sesuai jadwal blok, untuk jadwal mengupload materi dilakukan setiap hari Kamis. Untuk pembelajaran tatap muka, mahasiswa menyiapkan alat-alat yang digunakan untuk praktikum yang dilakukan secara langsung, dimana alat-alat tersebut sudah disediakan oleh sekolah, jadi mahasiswa hanya perlu mempersiapkannya. Pembelajaran tatap muka di SMK Negeri 1 Blitar jurusan TKJ dilakukan pada 
hari Senin sampai Kamis mulai pukul 07.00 sampai 10.00. Sedangkan jadwal pembelajaran tatap muka setiap mata pelajaran tiap minggunya berubah-ubah sesuai kebijakan dari jurusan.

\section{HASIL DAN PEMIBAHASAN}

Proses pembelajaran di sekolah merupakan alat kebijakn publik terbaik sebagai upaya peningkatan pengetahuan dan skill Tetapi sekarang kegiatan di sekolah berhenti dengan tiba-tiba karena adanya pandemi Covid-19 (Aji, 2020). Dalam pelaksanaan KPL kali ini, mahasiswa mengajar mata pelajaran Komputer dan Jaringan Dasar kelas X dengan $3 \mathrm{KD}$, yaitu mengenai perakitan komputer, pengujian perakitan komputer, dan konfigurasi BIOS pada computer disajikan pada Tabel 1. Adapun pelaksanaan KPL di SMK Negeri 1 Blitar pada masa pandemi Covid-19 dilakukan dengan 2 model pembelajaran, yaitu secara daring dan tatap muka.

Tabel 1. Kompetensi Dasar

\begin{tabular}{ll}
\hline \multicolumn{2}{c}{ Kompetensi Dasar } \\
\hline 3.2 Menerapkan perakitan komputer & 4.2 Merakit Komputer \\
3.3 Menerapkan pengujian perakitan komputer & 4.3 Menguji kinerja komputer \\
3.4 Menerapkan konfigurasi BIOS pada komputer & 4.4 Melakukan setting BIOS \\
\hline
\end{tabular}

\section{Pembelajaran Daring}

Pembelajaran daring adalah sistem belajar yang terbuka dan tersebar dengan menggunakan perangkat pedagogi yang dimungkinkan melalui internet dan teknologi berbasis jaringan untuk memfasilitasi pembentukan proses belajar dan pengetahuan melalui aksi dan interaksi yang berarti (Pakpahan \& Fitriani, 2020). Pada pembelajaran daring di SMK Negeri 1 Blitar seluruhnya dilakukan menggunakan E-Learning sekolah tanpa adanya WhatsApp Group dengan siswa maupun pembelajaran melalui video conference atau sejenisnya.

Untuk menunjang kegiatan pembelajaran daring, mahasiswa harus membuat media pembelajaran yang berupa materi dalam bentuk PPT dan tugas yang diupload di E-Learning sekolah, serta video pembelajaran yang diupload diYouTube. Pembelajaran daring mata pelajaran Komputer dan Jaringan Dasar setiap kelas dilakukan selama 2 minggu sekali sesuai jadwal blok, untuk jadwal mengupload materi dilakukan setiap hari Kamis, kemudian untuk pengumpulan tugas maksimal pada hari itu juga hingga pukul 15.30.

Selama pembelajaran daring, siswa mengikutinya dari rumah masing-masing. Masing-masing kelas diberi kesempatan untuk memahami materi dan mengerjakan tugas selama 2 minggu sekali (sesuai blok). Menurut (Wahyono et al., 2020), kurangnya kesadaran dinyatakan sebagai tantangan utama yang dihadapi oleh pendidik saat pembelajaran daring. Hal ini dapat dibuktikan dalam pelaksanaan KPL ini, bahwa waktu pengumpulan tugas siswa melebihi batas waktu yang ditentukan, yaitu hingga 2 minggu lebih. Untuk mengatasi hal tersebut, mahasiswa inisiatif menghubungi dan mengingatkan melalui WhatsApp siswa yang terlambat dalam pengumpulan tugas dan menanyakan kepada siswa tersebut mengenai alasan terlambat pengumpulan dan kendala yang dihadapi saat pengerjaan tugasnya.

Kendala yang kedua adalah pada saat kegiatan pembelajaran daring, penulis kesulitan memantau siswa karena kegiatan pembelajaran daring sepenuhnya dilakukan menggunakan E-learning sekolah, jadi penulis tidak memiliki Group WhatsApp dan tidak pernah melakukan pertemuan melalui video conference dengan siswanya dikarenakan mengikuti kebijakan dari sekolah. Akan tetapi, penulis diperbolehkan mencantumkan nomor WhatsApp ke dalam E-learning jika sewaktu-waktu terdapat pertanyaan, siswa dapat langsung menghubungi nomor yang telah tercantum. Mata pelajaran Komputer dan Jaringan Dasar dilakukan pada setiap hari Kamis. Berikut adalah jadwal mengajar praktikan dalam pembelajaran daring (Tabel 2).

Tabel 2 Jadwal Mengajar Daring

\begin{tabular}{lcc}
\hline \multicolumn{1}{c}{ Hari/Tanggal } & Kelas yang Diampu & Kompetensi Dasar yang Disampaikan \\
\hline Kamis, 13 Agustus 2020 & X TKJ 2 & $3.2 / 4.2$ \\
Kamis, 20 Agustus 2020 & Libur Hari Besar & Libur Hari Besar \\
Kamis, 27 Agustus 2020 & X TKJ 1 & $3.2 / 4.2$ \\
Kamis, 3 September 2020 & X TKJ 1 & $3.3 / 4.3$ \\
Kamis, 10 September 2020 & X TKJ 2 & $3.3 / 4.3$ \\
\hline
\end{tabular}




\begin{tabular}{ccc}
\hline Hari/Tanggal & Kelas yang Diampu & Kompetensi Dasar yang Disampaikan \\
\hline Kamis, 17 September 2020 & X TKJ 2 & $3.4 / 4.4$ \\
\hline
\end{tabular}

\section{Pembelajaran Tatap Muka}

Pada saat pembelajaran tatap muka, praktikan hanya berkesempatan melakukan satu kali, yaitu pada hari Kamis, 3 September 2020 dengan menyampaikan KD 3.2/4.2 dan 3.3/4.3 pada kelas X TKJ 2. Sarana dan prasarana untuk melakukan kegiatan pembelajaran di SMKN 1 Blitar sudah memadahi. Seperti pada KD 3.2 yaitu menerapkan perakitan komputer, dimana sekolah sudah menyediakan alat-alat berupa komponen CPU untuk dilakukan perakitan komputer, namun komponen tersebut belum tertata dengan baik sehingga pengajar sedikit kesulitan untuk menyiapkan komponen-komponen tersebut pada saat kegiatan pembelajaran tatap muka (luring). Hal ini dapat teratasi dengan baik karena siswa yang masuk untuk pembelajaran tatap muka hanya lima anak, sehingga pengajar hanya perlu menyiapkan masing-masing lima komponen dalam kegiatan pembelajaran tersebut.

Kendala yang kedua yaitu mengenai alokasi waktu, dimana mahasiswa diminta untuk menyampaikan KD 3.2/4.2 dan KD 3.2/4.2, sedangkan waktu yang diberikan hanya 3 jam, yaitu pukul 07.00 sampai dengan pukul 10.00. Jadi untuk mengatasi hal ini, mahasiswa hanya diminta untuk menyampaikan langsung materi yang berupa praktikum, sedangkan selebihnya disampaikan melalui E-Learning sekolah. Kendala yang paling utama yang dialami pendidik di tengah pandemi Covid-19 ini adalah pendidik dituntut untuk melakukan inovasi dalam proses pembelajaran khususnya pembelajaran daring (Tjandra, 2020). Solusinya adalah dengan cara pendidik harus memfasilitasi dengan perpustakaan kelas, modul, buku teks, dan buku-buku pendukung, serta yang terpenting adalah akses internet (Anugrahana, 2020).

Untuk kegiatan evaluasi, praktikan menyiapkan sebuah link google drive yang dibagikan kepada siswa. Jadi seluruh tugas siswa terkumpul dalam link tersebut. Tugas yang diberikan setiap KD memiliki konsep yang sama, yaitu berjumlah lima soal uraian dan satu soal membuat kesimpulan. Tugas dikerjakan dengan ditulis tangan, kemudian difoto dan dikumpulkan ke link google drive dalam format pdf. Penilaian dilakukan oleh mahasiswa KPL sendiri, dimana siswa yang mengumpulkan terlambat akan diberi pengurangan nilai untuk membedakan dengan siswa yang mengumpulkan tepat waktu. Menurut (Anugrah, 2020), seiring berjalannya waktu muncul banyak permasalahan dalam implementasi pembelajaran daring, diantaranya adalah tugas guru yang terlalu banyak dan keluhan soal kuota dan jaringan internet yang serba terbatas.

\section{SIMIPULAN}

Secara umum, kegiatan KPL di SMK Negeri 1 Blitar berjalan dengan baik, namun terdapat beberapa kendala yang dialami, salah satunya adalah mahasiswa kesulitan dalam memantau siswa, dikarenakan proses pembelajaran daring dilakukan sepenuhnya menggunakan E-Learning sekolah tanpa adanya WhatsApp Group dengan siswa ataupun video conference. Agar kegiatan KPL selanjutnya dapat berjalan dengan lebih maka hendaknya mahasiswa dengan siswa diperbolehkan membuat WhatsApp Group untuk memudahkan komunikasi. Mahasiswa juga diharapkan dapat memanfaatkan waktu dengan baik agar tidak keteteran ketika mendapatkan tugas tambahan dari guru pamong maupun Dosen Pembombing Lapangan (DPL).

\section{DAFTAR RUJUKAN}

Aji, R. H. S. (2020). Dampak Covid-19 pada pendidikan di Indonesia: Sekolah, keterampilan, dan proses embelajaran. Salam: Jurnal Sosial Dan Budaya Syar-I, 7(5), 395-402.

Anugrah, D. (2020). Dinamika pembelajaran daring di tengah pandemi Covid-19 (Vol. 30).

Anugrahana, A. (2020). Hambatan, solusi dan harapan: Pembelajaran daring selama masa pandemi Covid-19 oleh guru sekolah dasar. Scholaria: Jurnal Pendidikan Dan Kebudayaan, 10(3), 282-289.

Chandra, E. (2018). Youtube, citra media informasi interaktif atau media penyampaian aspirasi pribadi. Jurnal Muara Ilmu Sosial, Humaniora, Dan Seni, 1(2), 406-417.

Fatahillah, F., Zainuddin, M., Kasau, R., \& Samad, M. R. (2020). Pengembangan pembelajaran berbasis dalam jaringan (daring) di SMK. Prosiding Seminar Nasional Fakultas Teknik UNM.

Fitriyani, Y., Fauzi, I., \& Sari, M. Z. (2020). Motivasi belajar mahasiswa pada pembelajaran daring selama pandemik Covid-19. Jurnal Kependidikan: Jurnal Hasil Penelitian Dan Kajian Kepustakaan Di Bidang Pendidikan, Pengajaran Dan Pembelajaran, 6(2), 165-175. 
Hashona, A. H. (2016). Kajian pelaksanaan praktik pengalaman lapangan (PPL) mahasiswa fakultas ilmu tarbiyah dan keguruan IAIN Walisongo Semarang. Cendekia: Jurnal Kependidikan Dan Kemasyarakatan, 12(2), 333-352.

Idris, H. (2018). Pembelajaran model blended learning. Jurnal Ilmiah Iqra', 5(1), 61-73.

Mustafa, P. S. (2020). Penerapan kajian dan praktik lapangan pada mahasiswa pendidikan olahraga di Universitas Negeri Malang (Mata kuliah: Pembelajaran Tenis Meja Dan Metodologi Penelitian). Biormatika: Jurnal Ilmiah Fakultas Keguruan Dan Ilmu Pendidikan, 6(02), 12-28.

Pakpahan, R., \& Fitriani, Y. (2020). Analisa pemanfaatan teknologi informasi dalam pembelajaran jarak jauh di tengah pandemi virus Covid-19. Journal of Information System, Applied, Management, Accounting and Research, 4(2), 3036 .

Pradhitya, V. E. C., Kuswandi, D., \& Wedi, A. (2018). Persepsi mahasiswa pada kajian dan praktik lapangan jurusan Teknologi Pendidikan. JINOTEP (Jurnal Inovasi Dan Teknologi Pembelajaran) Kajian Dan Riset Dalam Teknologi Pembelajaran, 4(2), 63-69.

Sjukur, S. B. (2012). Pengaruh blended learning terhadap motivasi belajar dan hasil belajar siswa di tingkat SMK. Jurnal Pendidikan Vokasi, 2(3), 368-378.

Syarif, I. (2012). Pengaruh model blended learning terhadap motivasi dan prestasi belajar siswa SMK. Jurnal Pendidikan Vokasi, 2(2), 234-249.

Tjandra, D. S. (2020). Impelementasi pembelajaran pendidikan agama Kristen di abad 21. SIKIP: Jurnal Pendidikan Agama Kristen, 1(1), 1-10.

Wahyono, P., Husamah, H., \& Budi, A. S. (2020). Guru profesional di masa pandemi COVID-19: Review implementasi, tantangan, dan solusi pembelajaran daring. Jurnal Pendidikan Profesi Guru, 1(1), 51-65. 